\title{
DISTRIBUTION OF WESTERN JUNIPER SEEDS ACROSS AN ECOTONE AND IMPLICATIONS FOR DISPERSAL
}

\author{
Lindsay A. Dimitri ${ }^{1}$ and William S. Longland ${ }^{1,2}$
}

\begin{abstract}
AвSTRACT-Western juniper woodlands have been the focus of extensive research and management due to range expansion and infilling that began over a century ago. Understanding juniper seed dispersal is vital to identifying processes behind this expansion. Dispersal of Juniperus seeds has generally been attributed to consumption of female juniper cones ("berries") by frugivorous birds and mammals, which then defecate seeds after gut passage. However, recent studies have found that scatter-hoarding rodents harvest and cache juniper seeds. Rodents caching and failing to recover juniper seeds that have been removed from feces may constitute a secondary mode of dispersal that accounts for more seedling recruitment than primary dispersal by frugivores. We considered implications of juniper seed dispersal by frugivorous birds and subsequent removal of bird-passed seeds and secondary dispersal by scatter-hoarding rodents by examining the distribution of western juniper seeds after dispersal by birds along transects extending from a juniper woodland into a 30-year-old burn. In winter 2016, we surveyed 4 microsites (open, shrub canopy, juniper canopy, and rock) across the wooded and burned habitats for bird-dispersed seeds and repeated surveys 6 months later to determine the degree to which rodents had removed seeds. Western juniper seeds were more abundant in winter than in summer surveys, in the woodland than in the burned habitat, and under juniper canopies compared with the other microsites. There was a significant inverse relationship between the number of bird-dispersed seeds in each microsite and the distance of the microsite from the woodland. We suggest that scatter-hoarding rodents are important to the dispersal process, as they remove seeds from high-density microsites, such as tree canopies, and redistribute them. We consider the relevance of these findings to western juniper woodlands experiencing infilling and expansion, as well as to those impacted by climate-induced mortality.
\end{abstract}

RESUMEN.-Bosques de enebro occidental han sido el foco de investigación y gestión debido a la expansión de rango y llenado que comenzó hace más de un siglo. Comprensión de semillas de enebro dispersión es vital para identificar los procesos detrás de aumentos en densidad y gama. Dispersión de semillas de Juniperus generalmente ha sido atribuida al consumo de conos femeninos enebro (también conocido como "bayas") por aves frugívoras y mamíferos, que entonces defecan las semillas después del paso de la tripa. Sin embargo, estudios recientes han encontrado que roedores de acaparamiento de la dispersión cosechan y ocultan semillas de enebro. Roedores ocultando y fallando de recuperar semillas de Juniperus que se han quitado de las heces pueden constituir un modo secundario de dispersión representa el mayor reclutamiento de plántulas que hace dispersión primaria frugívoras. Se consideraron las implicaciones de la dispersión de semillas de enebro por aves frugívoras y la dispersión acaparamiento roedores examinando la distribución de semillas de enebro occidental después de la dispersión por aves de un bosque de enebro intacta en una quemadura de 30 años de edad. En invierno 2016, encuestamos cuatro micrositios (pabellón de enebro, arbusto pabellón, roca, abierta) a través de los hábitats boscosos y quemados para semillas dispersadas por aves y repetimoss encuestas seis meses más tarde determinar el grado a cuales roedores han eliminado semillas. Semillas de enebro occidental fueron significativamente más abundantes en invierno en comparación con encuestas de verano, en los bosques en comparación con el hábitat quemado y debajo de los pabellones de enebro en comparación con los otros micrositios. Había una relación inversa significativa entre el número de aves que dispersan semillas en cada micrositio y distancia del hábitat del bosque. Sugerimos que los roedores de acaparamiento de dispersión son importantes al proceso de dispersión, ya que quitar las semillas de microsites de alta densidad tales como toldos de árbol y las redistribuyen. Consideramos la relevancia de estos hallazgos a los bosques de enebro occidental experimenta llenado y expansión, así como a los afectados por mortalidad inducidos por el clima.

For more than a century, Juniperus species across the western United States have expanded into shrublands and have increased in density within existing stands (Miller and Wigand 1994, Weisberg et al. 2007, Romme et al. 2009). Grazing, changing fire regimes, increased atmospheric $\mathrm{CO}_{2}$, favorable climatic conditions, and recovery from past disturbance have been cited as potential factors fueling woodland expansion and infilling (Burkhardt and Tisdale 1976, Miller and Rose 1999, Van Auken 2000, Knapp et al. 2001,

\footnotetext{
${ }^{1}$ USDA, Agricultural Research Service, Great Basin Rangelands Research Unit, 920 Valley Road, Reno, NV 89512.
}

${ }^{2}$ Corresponding author. E-mail: bill.longland@ars.usda.gov 
Baker and Shinneman 2004), although causes likely vary among different juniper species (Romme et al. 2009). Land managers have spent millions of dollars to counteract this expansion, and studies on management practices have shown variable results, especially when it comes to impacts on wildlife (Bombaci and Pejchar 2016) and long-term juniper recruitment (Redmond and Barger 2013).

By contrast to population proliferation, some juniper woodlands have experienced high mortality rates. Climate-induced droughts have caused substantial mortality in southwestern piñon-juniper woodlands, counteracting their expansion (Clifford et al. 2011). Soulé and Knapp (2007) described a die-off of western juniper woodlands in central Oregon that occurred during an abnormally early cold spell that was followed by drought. Climateinduced tree mortality due to drought and heat stress has been observed in a variety of woodland ecosystems worldwide and is expected to increase with rising global temperatures (Allen et al. 2010). Tree density has been found to directly affect mortality in piñonjuniper woodlands within the Great Basin (Greenwood and Weisberg 2008), so infilling could create conditions that increase tree mortality during stressful conditions. A better understanding of the reproductive ecology of these junipers, particularly of factors that influence seedling recruitment, such as seed dispersal, is vital to developing informed management decisions in these fluctuating woodland ecosystems.

Dispersal of seeds away from parent plants is an important component of plant population dynamics that influences gene flow and genetic variation (Howe and Miriti 2004, Calviño-Cancela et al. 2012). Seed dispersal helps seeds and seedlings escape positive density-dependent mortality that occurs under the parent canopy, where there are higher levels of seed predation, herbivory, and pathogen exposure (Janzen 1970, Connell 1971). Seeds are dispersed away from the parent plant through abiotic (wind, gravity, etc.) or biotic (animal assisted) processes, the latter of which can give seeds advantages that are less likely attained through abiotic dispersal (Chambers and MacMahon 1994). For example, frugivorous birds and mammals can disperse large seeds farther than gravity or wind alone. Birds can also disperse seeds to favorable microsites, such as areas beneath shrub canopies. However, frugivorous birds leave dense clumps of seeds under frequently used perches (Chavez-Ramirez and Slack 1994, Vander Wall and Beck 2012). Mammals such as coyotes, Canis latrans, and gray foxes, Urocyon cinereoargenteus, can disperse juniper seeds farther distances than birds, but their feces often contain many clustered seeds and are mostly found in open areas on trails or roads, which are usually unsuitable microsites for germination (Chavez-Ramirez and Slack 1993, Schupp et al. 1997). Dispersal by frugivorous birds and mammals can thus result in high seed density, facilitating increased seed predation and seedling competition (Spiegel and Nathan 2010). Scatter-hoarding rodents redistribute seeds from areas of high seed density by dispersing them throughout their home range and burying them in caches (Vander Wall and Beck 2012). Seed burial can allow seeds to escape predation and desiccation on the soil surface (Chambers and MacMahon 1994) and is required for successful germination and seedling establishment in western juniper (Longland and Dimitri 2016). Large seeds such as juniper do not easily move vertically in the soil column (Chambers et al. 1991), so burial of seeds by scatter-hoarding rodents provides advantages that are less likely obtained through purely abiotic dispersal.

Junipers produce female cones resembling berries that enclose their seeds. Like true fruits, juniper berries are consumed by frugivorous birds and mammals, and their seeds are dispersed in feces (Adams and Thornburg 2010; Fig. 1). It has long been assumed that frugivorous birds and, to a lesser extent, mammals are the main seed dispersers of all Juniperus species (Adams and Thornburg 2010). Although rodents have been observed removing berries from beneath juniper canopies (Horncastle et al. 2004) and seeds from carnivore scat (Chavez-Ramirez and Slack 1993), they were considered seed predators in both cases. Nevertheless, in addition to being seed predators, rodents can act as important dispersers through their seed caching activities (Vander Wall et al. 2005). For example, seed removal from frugivore feces by scatterhoarding rodents can spread seeds over a larger area and move them to microsites where they have a greater germination potential (Enders and Vander Wall 2012, Vander Wall 


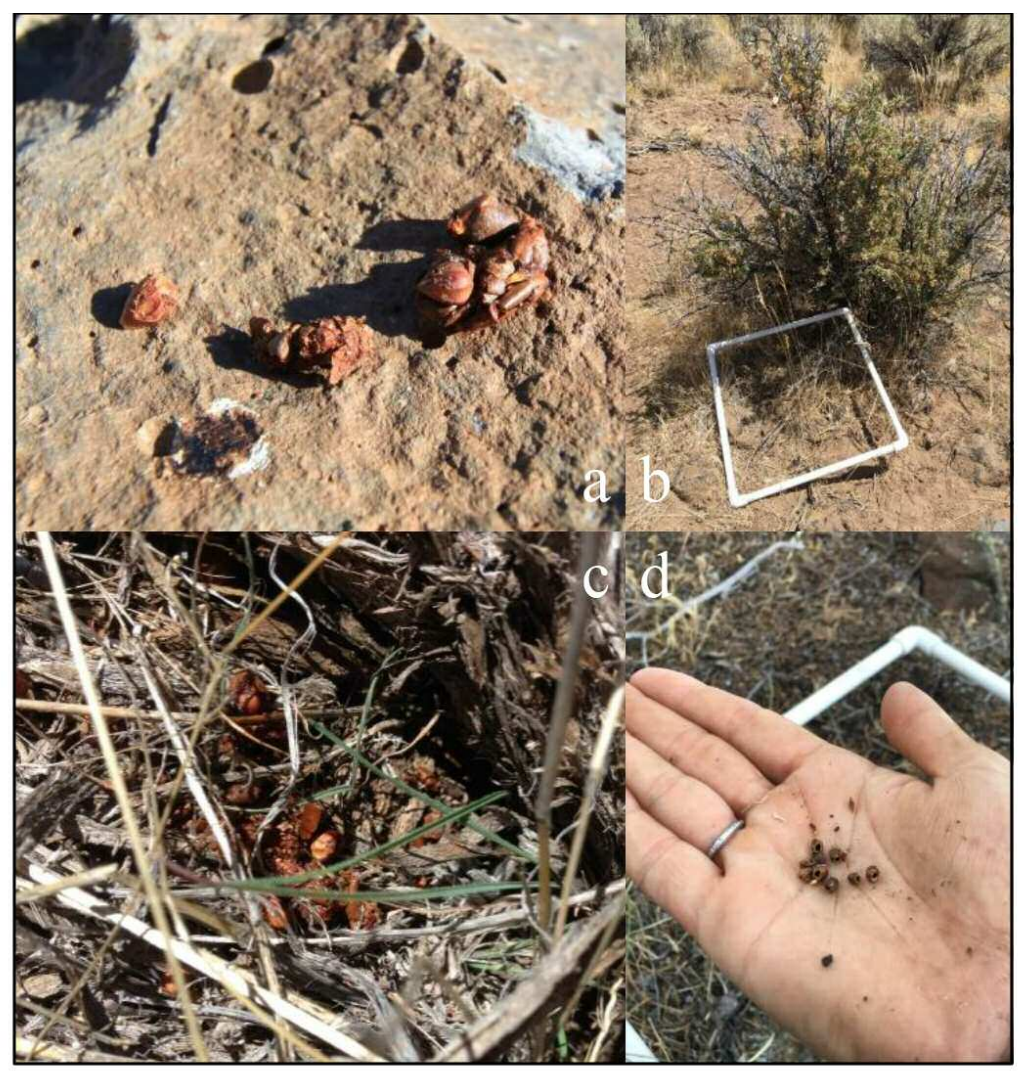

Fig. 1. Western juniper seeds from bird feces and microsites from our Shinn Peak site in northeastern California. Clockwise from top left: (a) western juniper seeds in bird feces on a rock microsite, (b) sampling frame under shrub canopy microsite, (c) seeds in bird feces under shrub canopy, and (d) western juniper seeds eaten by rodents found under a juniper canopy.

and Beck 2012). Dispersal of seeds by frugivores and then by scatter-hoarding rodents is an example of diplochory, in which seeds are dispersed by 2 sequential modes and may thus benefit from distinct advantages offered by each of these dispersal modes (Vander Wall and Longland 2004, Vander Wall and Beck 2012).

There is sufficient evidence to suggest that dispersal of western juniper seeds is an example of diplochory. Specifically, in a field experiment frugivorous birds removed whole berries from beneath western juniper canopies, but ignored juniper seeds. Some scatterhoarding rodents also removed whole berries, but generally only took seeds cleaned of pulp, either by the researchers or by passage through the guts of frugivorous birds (Longland and Dimitri 2016). Furthermore, Dimitri (2016) followed the fate of both western and Utah juniper seeds removed by rodents and found many of them buried in scatter-hoard caches. Rodent scatter-hoards are important sources of seedling recruitment in many plants, including piñon pine (Pinus monophylla), which co-occurs with juniper over much of the arid southwest (Hollander and Vander Wall 2004).

Birds may facilitate either short- or longdistance dispersal, but rodent dispersal is limited to the shorter distances over which they move (Holthuijzen et al. 1987, Horncastle et al. 2004, Vander Wall and Beck 2012). Consequently, if rodent dispersal through seed caching proves to be the terminal stage in seedling recruitment of western juniper, focusing management and control efforts at the edges of stands could be a fruitful strategy for reducing the rate of juniper expansion. Moreover, spatial patterns of seedling establishment differ predictably between seeds 
dispersed by birds and seeds dispersed by small mammals, with the former resulting in aggregated seedling establishment and the latter resulting in more scattered establishment patterns (Vander Wall and Beck 2012). Schupp et al. (1999) suggested that since some rodents are abundant along ecotones, they could be responsible for the expansion of juniper woodlands into shrublands. Understanding seed dispersal syndromes can contribute to the development of spatial models of juniper expansion, clarify the degree to which seed dispersers may contribute to woodland expansion, and provide required information to assist in developing effective control programs.

For this study we examined the distribution of western juniper seeds among different microsites after dispersal by birds. We also tested whether distance from the edge of a juniper woodland affected juniper seed distribution across an ecotone delineating intact woodland and open burned woodland. Considering their mobility, it seems intuitive that frugivorous birds would move frequently throughout such a habitat mosaic and deposit seeds randomly across the landscape. However, because juniper berries passing through the guts of frugivorous birds have short retention times (often $<1 \mathrm{~h}$ ) and because birds feed and perch in junipers (Chambers et al. 1999), we predicted that seed numbers would decrease as distance to the woodland edge increased. We predicted that in both wooded and burned areas, seeds would be more clustered on the ground surface in microhabitats where birds perch (tree and shrub canopies, on and around large rocks) as compared to the seed distribution in interspaces between shrubs and trees. We expected that seeds would be removed from these microhabitats by granivorous rodents, and we conducted rodent livetrapping to determine whether habitat type (woodland or burned) affected the distribution of scatter-hoarding rodent species.

\section{Methods}

\section{Site Description}

The study was conducted at Shinn Peak in northeastern California (Lassen Co.). Our long-term study plot covers approximately 1.8 ha, half of which includes an area that was burned about 30 years ago. Most of the standing dead trees have been removed by wood cutting activity, but a few live trees remain. The eastern edge of the plot includes a rocky outcropping with large boulders where scattered mature western juniper trees survived the fire. Native plants in the burned portion of the plot include shrubs, such as mountain big sagebrush (Artemisia tridentata), low sagebrush (A. arbuscula), silver wormwood (A. ludoviciana), and rubber rabbitbrush (Ericameria nauseosa var. speciosa); grasses, such as squirreltail (Elymus elymoides) and Great Basin wildrye (Leymus cinereus); woolly sedge (Carex pellita); and forbs, such as silvery lupine (Lupinus argenteus), royal penstemon (Penstemon speciosus), buckwheat (Eriogonum spp.), and spiked larkspur (Delphinium stachydeum). The understory has been invaded by tall tumblemustard (Sisymbrium altissimum), cheatgrass (Bromus tectorum), and rattlesnake brome (B. briziformis). Rubber rabbitbrush and Great Basin wildrye are the most dominant native plants in the burned area from the forest edge to the rocky outcropping along the eastern edge. On this portion of the plot, cheatgrass occurs in varying densities in interspaces among shrubs and junipers but is sparse or absent elsewhere, including the rocky area.

The other half of the study site was juniper woodland, consisting of mostly postsettlement trees and a shrub understory consisting of antelope bitterbrush (Purshia tridentata), mountain big sagebrush, scattered green ephedra (Ephedra viridis), and wax currant (Ribes cereum), as well as native bunchgrasses, perennials, and forbs. Nonnative invasive annuals such as thistle (Cirsium spp.), flixweed (Descurainia sophia), and cheatgrass were common in interspaces near the burned half of the plot but were sparse or absent in other areas of the woodland. The site would be described as a phase II juniper woodland based on the classification scheme of Miller et al. (2005).

\section{Seed Surveys}

Surveys of western juniper seeds dispersed by birds were conducted on 24 and 25 February 2016 along 3 parallel transects $20 \mathrm{~m}$ apart and $285 \mathrm{~m}$ long. We chose to sample seeds at this time because most juniper berries had been consumed by frugivorous birds and because high densities of seeds scattered on the ground indicated that rodents had not yet removed a major portion of the seed rain. 
The 3 transects ran the length of our longterm study site, with 2 transects along the edges and a third running up the center of the plot. Each linear transect had 20 sampling points spaced $15 \mathrm{~m}$ apart. Of the 20 points, 10 were in the woodland and 10 were in the burned area. We counted seeds in 4 distinct microhabitats closest to each point: open spaces, under living or dead shrub canopies, under juniper canopies, and on rocks (Fig. 1). Juniper canopy microsites were not included when the nearest tree was $>15 \mathrm{~m}$ from the sampling point. At each sampling point, we tossed a $50 \times 50-\mathrm{cm}$ sampling frame into each microsite type in an attempt to randomize placement of the frames and counted the juniper seeds that were visible on the surface within the frames. As it was not possible to throw frames into the center of the shrub canopy, shrub canopy edges were sampled; thus, seeds dispersed under shrub canopies may be underestimated. Old, eaten, or chewed seeds, which are all easily discernable from new seeds defecated by birds, were not counted. We resurveyed these microsites along the same transects on 9 and 10 August 2016, after rodents would have had an opportunity to encounter and remove seeds over the spring and summer.

\section{Data Analysis}

To characterize postdispersal seed distributions across the study site, we employed a mixed-model analysis of variance (mmANOVA, PROC MIXED in SAS 2012) using number of seeds counted at each point as the dependent variable and season (winter or summer), habitat (burned or woodland), microsite (open, shrub, tree, or rock), and their interaction terms as independent variables. Points nested within replicate sampling lines were a random term. The model included 3 planned contrasts: (1) tree and shrub canopy microsites that provide protective cover for rodents versus open and rock microsites which lack cover; (2) rock, shrub, and tree microsites that provide perches for birds versus open microsites lacking perches; and (3) trees versus other microsites. We also examined Tukey-adjusted differences of least-squares means among microsites to determine which pairs differed in seed counts. Regression analysis (PROC REG in SAS 2012) was used to determine whether the number of seeds in each of the 4 surveyed microsites (the dependent variable) differed as a function of distance to the woodland edge. Season was included as a qualitative dependent variable in the regressions for each microsite. However, the season effect and the seed numberby-season interactions were significant for all microsites, so we ran separate regressions for each season.

\section{Small Mammal Trapping}

We livetrapped small mammals on a $4 \times 20$ trap grid in May 2016 over 3 consecutive days and nights using Sherman live traps (H.B. Sherman Traps, Inc., Tallahassee, FL). The trapping grid was superimposed on seed sampling transects, so that half of the trap stations were within juniper woodland and half were in the burned area. Traps were baited with a commercial birdseed mix and set with 15-m spacing between adjacent trap stations and traplines. Rodents were identified to species, given uniquely numbered ear tags in order to identify recaptures, and released at the point of capture.

\section{REsults}

In winter surveys we counted a total of 5712 seeds across the 4 microsites, of which $4842(85 \%)$ were found in the woodland. During summer surveys only 450 seeds were counted, of which 397 (88\%) were found in the woodland. Because of these differences, the mmANOVA on the number of seeds found in the microsites surveyed yielded significant effects of season $\left(F_{1,392}=80.95, P<0.0001\right)$ and habitat $\left(F_{1,63.9}=31.77, P<0.0001\right)$. Microsite was also significant $\left(F_{3,393}=66.34\right.$, $P<0.0001)$, as the majority of seeds were found under juniper tree canopies (Fig. 2). Interaction effects were also highly significant $(P<0.0001$ in all cases $)$, largely because seasonal effects differed between burned and woodland habitats (seeds were depleted in both from winter to summer, but to a greater extent in the burned area) and among microsites (winter to summer depletion tended to be more complete on rocks and in open spaces than under tree and shrub canopies). Planned contrasts indicated that (1) more seeds were found in tree and shrub canopy microsites, which provided protective cover, than in the 2 exposed microsites $\left(F_{1,394}=90.45\right.$, 


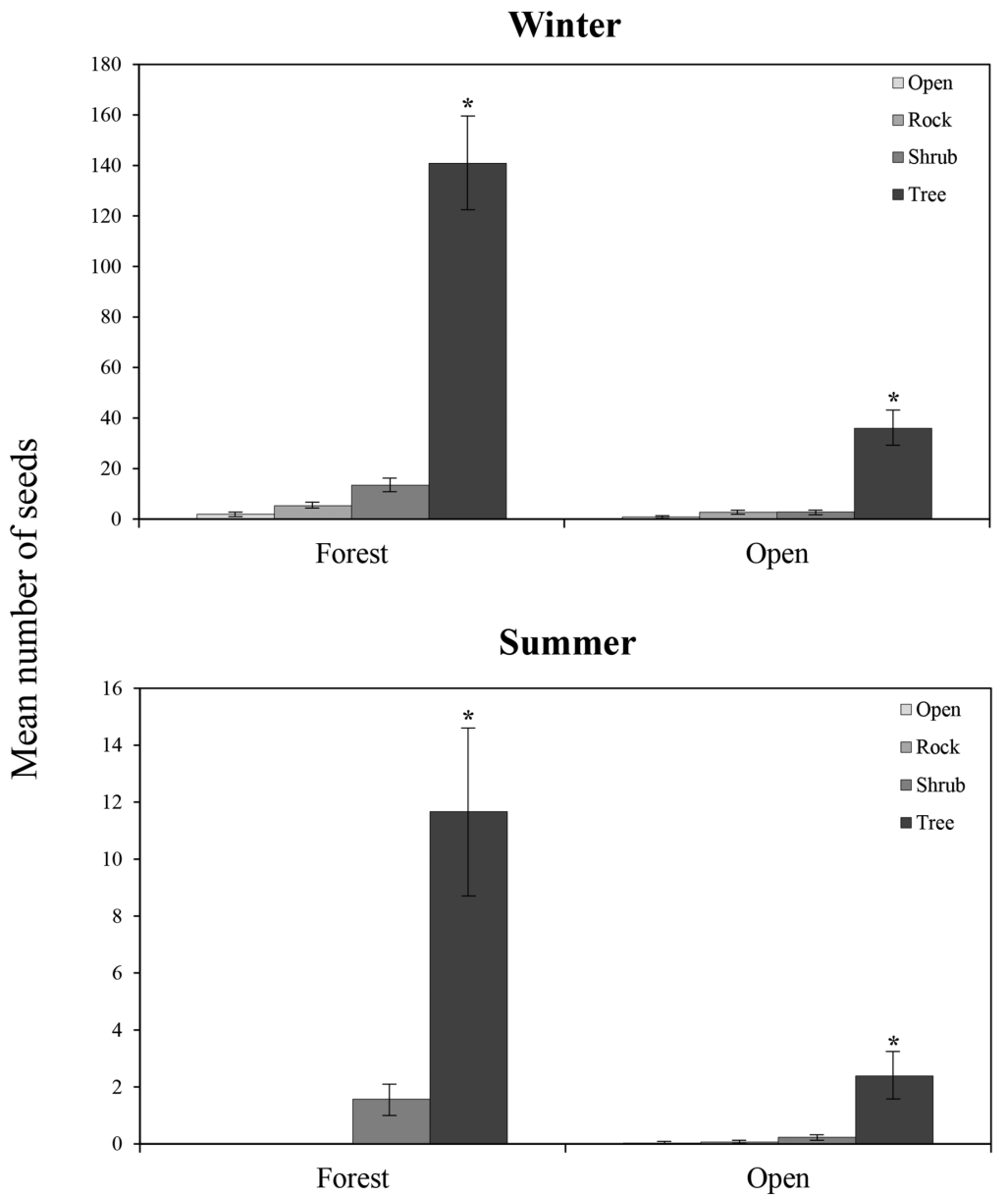

Fig. 2. Mean number of western juniper seeds $( \pm$ SE) found in microsites surveyed across habitats in winter (top) and summer (bottom). Tree canopies had significantly more seeds (*) than any other microsite in both seasons based on differences of least-squares means.

$P<0.0001) ;(2)$ more seeds occurred in microsites providing perches for birds (tree, shrub, rock) than in open microsites $\left(F_{1,390}=35.22\right.$, $P<0.0001$ ); and (3) more seeds occurred under tree canopies than in any of the other 3 microsites $\left(F_{1,405}=107.82, P<0.0001\right)$. Differences of least-squares means corroborated the latter result, as numbers of seeds under tree canopies were significantly greater than in each of the other microsites $(P<0.0001$ in all cases), while all other microsite pairs yielded no significant differences $(P>0.70$ in all cases).

Winter sampling yielded much higher seed counts than summer sampling, and regressions showed a significant inverse relationship in winter between distance from the woodland edge and number of juniper seeds sampled for shrub $(t=-2.46, \mathrm{df}=1, P=0.0168)$ and tree microsites $(t=-3.74$, df $=1, P=0.0005$; Fig. 3). Although nonsignificant, this inverse relationship also occurred in winter for open $(t=-2.00, \mathrm{df}=1, P=0.0502)$ and rock microsites $(t=-1.90, \mathrm{df}=1, P=0.0622)$. In summer samples, there were no significant relationships between distance from the woodland edge and number of juniper seeds for any microsite.

We trapped 7 species of small mammals in May 2016 (Table 1), of which 5 are known to make scatter-hoard caches (California kangaroo rat [Dipodmys californicus], deer mouse [Peromyscus maniculatus], piñon mouse [Peromyscus truei], Great Basin pocket mouse 


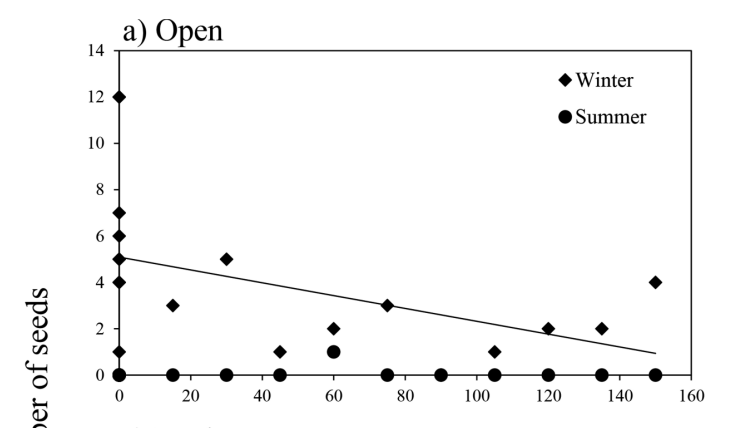

b) Shrub

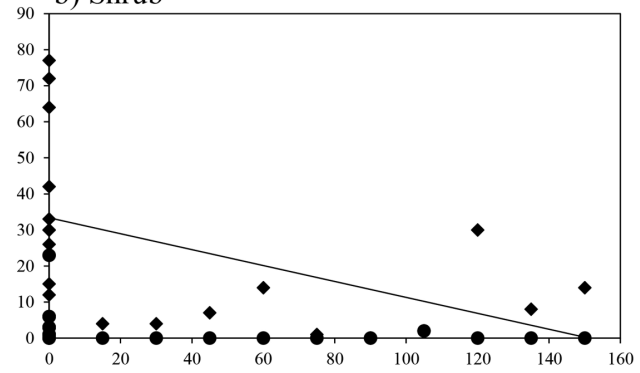

c) Rock
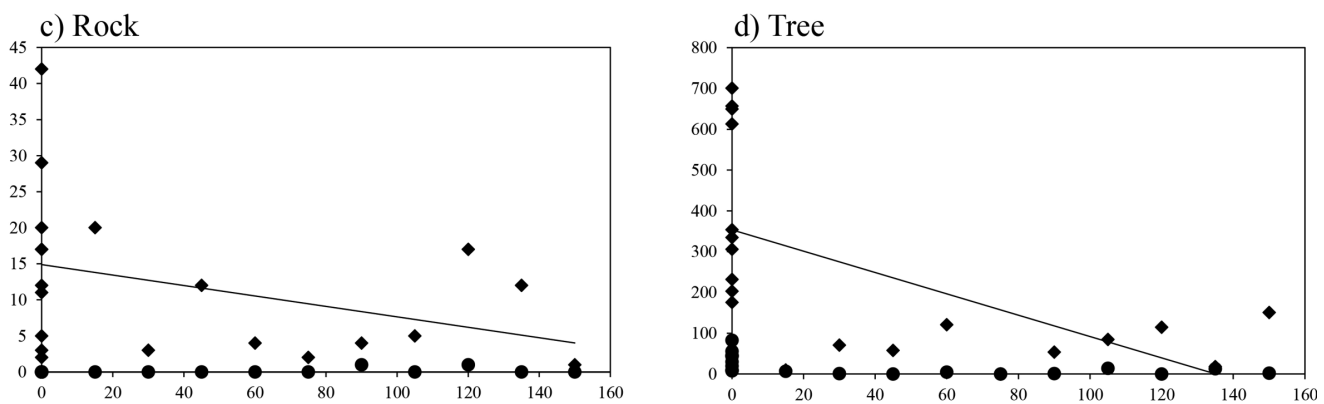

Distance to forest edge $(\mathrm{m})$

Fig. 3. Number of western juniper seeds sampled during winter (diamonds) and summer (circles) 2016 in each of 4 microsites as a function of distance to the edge of the juniper woodland. Regression lines are shown for winter samples. Note that $y$-axes are scaled differently in each panel, reflecting differences among microsites in numbers of bird-dispersed seeds.

TABLE 1. Numbers of small mammal species captured by live-trapping in juniper forest and open (burned forest) habitat during May 2016.

\begin{tabular}{lcc}
\hline & \multicolumn{2}{c}{ Number of trap captures } \\
\cline { 2 - 3 } Species & Forest & Open \\
\hline $\begin{array}{l}\text { Deer mouse (Peromyscus } \\
\quad \text { maniculatus) }\end{array}$ & 6 & 4 \\
$\begin{array}{l}\text { Piñon mouse (Peromyscus truei) } \\
\text { California kangaroo rat } \\
\quad(\text { Dipodomys californicus) }\end{array}$ & 3 & 0 \\
$\begin{array}{c}\text { Great Basin pocket mouse } \\
\quad \text { Perognathus parvus) }\end{array}$ & 16 & 11 \\
$\begin{array}{l}\text { Yellow-pine chipmunk (Tamias } \\
\text { amoenus) }\end{array}$ & 2 & 13 \\
$\begin{array}{c}\text { Golden-mantled ground squirrel } \\
\quad \text { Callospermophilus lateralis) }\end{array}$ & 0 & 2 \\
$\begin{array}{l}\text { Dusky-footed woodrat (Neotoma } \\
\text { fuscipes) }\end{array}$ & 2 & 0 \\
TotaL CAPTUREs & 34 & 30 \\
\hline
\end{tabular}

[Perognathus parvus], and yellow-pine chipmunk [Tamias amoenus]). Two of the scatterhoarding species, the piñon mouse and the yellow-pine chipmunk, were only trapped in the wooded area of the site. The other 3 species were captured in both habitats, although the Great Basin pocket mouse appeared to be more abundant in the burned habitat (Table 1).

\section{Discussion}

Berry production of western juniper typically shows high spatial and temporal variability (Miller et al. 2005), and insufficient berry production at a second long-term study site precluded us from replicating our study. The winter of 2015/2016 was a mast year for western juniper at our site, an event which generally occurs every $2-4$ years. During summer seed surveys, western juniper trees across this site had very few developing cones, indicating that there would not be another year of substantial seed production for the following 2 winters, as berries take 2 years to ripen. As a result, the opportunity for temporal replication was also limited. Despite the limits on the generality of our results, our study offers new insights into an understudied aspect of juniper dispersal, which is removal and secondary dispersal of western juniper seeds by scatter-hoarding rodents after preliminary dispersal by birds (Longland 
and Dimitri 2016), an example of diplochory (Vander Wall and Longland 2004).

Our seed surveys showed that western juniper seeds were clustered under tree canopies after consumption by frugivorous birds when compared to shrub canopy, open, and rock microsites regardless of habitat (burned or woodland) or season (winter or summer; Fig. 2). Microsites with perches, such as rocks, trees, and shrubs, had more seeds overall than open microsites, reflecting the importance of frugivorous birds as primary seed dispersers of western juniper. As we predicted, seeds were more abundant in the woodland than in the burned habitat, and seed abundance decreased in all 4 microsites as distance to the woodland edge increased. Vastly more seeds were found in winter than in summer. We attribute the reduction of seeds on the soil surface to rodents, many of which are scatterhoarders that actively remove juniper seeds (Dimitri 2016, Longland and Dimitri 2016). Rodent activity was evident during summer surveys, as numerous eaten or chewed seeds were apparent (Fig. 1d).

We have previously demonstrated that rodents remove seeds of both western and Utah juniper at variable rates, sometimes over an extended period of time, which we believe is largely attributable to variation in availability of alternate seed species that are preferred to juniper (Dimitri 2016, Longland and Dimitri 2016). However, while this certainly could influence absolute rates of seed removal, it is likely that relative removal rates from the various microsites we sampled would not vary with availability of alternate seed resources. Similarly, although we did not determine locations where rodents cached juniper seeds in this study, preferred caching microsites are unlikely to be altered by either juniper seed removal rates or availability of alternate seeds. Therefore, we argue that the qualitative patterns of microsite-specific seed removal we measured at Shinn Peak and the importance of diplochory as a dispersal strategy would remain, regardless of these factors.

Two scatter-hoarding species, the piñon mouse, which was recently found to be the main secondary disperser of western juniper seeds (Dimitri 2016), and the yellow-pine chipmunk, were only captured in woodland habitat during small mammal trapping. However, other rodents that may act as secondary dispersers occurred in the burned habitat. Great Basin pocket mice, which scatter-hoard juniper seeds, and California kangaroo rats, which make some scatter-hoard caches but mostly larder-hoard juniper seeds, were found across the site (Dimitri 2016). Great Basin pocket mice were captured more than twice as often in the burned than in the woodland habitat. We have conducted small mammal live-trapping at this site at least once annually over the past 6 years, and the species-specific patterns of habitat use noted here from our 2016 trapping are consistent over years (unpublished data). High densities of invasive plants can impact rodent activity by restricting movement (Reider et al. 2010), but our trapping data indicate that multiple rodent species are present and active throughout the burned area at our site. Some of our trap stations are in areas where cheatgrass is at its most dense on our site, and California kangaroo rats, Great Basin pocket mice, and deer mice are regularly captured.

We have observed mammals including gray foxes, coyotes and desert cottontails (Sylvilagus audubonii) consuming western juniper berries in trail camera videos taken at our site. Schupp et al. (1997) suggested coyotes were the only effective frugivorous mammalian disperser of western juniper seeds. We have observed coyote and gray fox feces filled with western juniper seeds along game trails at our site, but all of the seeds we counted in this study were clearly attributable to primary dispersal by frugivorous birds. Mammal scat is easy to discern from that of birds and it degrades too slowly in arid environments to have decomposed to the point of being undetectable within the time frame of the study.

Previous studies have found that most juniper seedling recruitment occurs under shrubs (Burkhardt and Tisdale 1976, Schupp et al. 1999, Redmond and Barger 2013), but we found that juniper tree canopies contain far more seeds. Although shrubs were second among microsites after tree canopies in numbers of bird-defecated seeds, we suggest that, rather than seedling recruitment being a direct result of primary dispersal by birds, scatterhoarding rodents are responsible for much of the seedling recruitment under shrubs because they bury seeds in superficial caches there (Dimitri 2016). First, nearly all seeds deposited by birds under shrubs disappeared between 
our winter and summer samples, and juniper seed removal is attributable almost entirely to rodents (Dimitri 2016, Longland and Dimitri 2016). Moreover, seed burial is essential for western juniper seedling emergence (Longland and Dimitri 2016), and, for relatively large seeds like juniper, scatterhoarding rodents bury far more seeds and do it more efficiently than can be achieved through random or abiotic means (Vander Wall 1990, Chambers et al. 1991).

Seed dispersal patterns of birds and scatterhoarding rodents likely contribute to infilling, or an increase in density in western juniper woodlands, and to range expansion, but their effect on the latter is probably spatially limited. Even on the small scale of our sampling, which only recorded dispersal to slightly more than $100 \mathrm{~m}$ into a burned area, we found a measurable reduction in bird-passed juniper seeds in all microsites with increasing distance from the woodland edge. This finding implies that availability of bird-passed seeds diminishes at greater distances from juniper woodlands, which should make seedling recruitment rare regardless of whether it occurs directly from primary dispersal by birds or through diplochory with rodents acting as secondary dispersers. Additionally, some scatter-hoarding rodent species, such as the piñon mouse and the yellow-pine chipmunk, have a strong affinity for woodland habitat, and are thus unlikely to disperse seeds away from the woodland edge. However, other scatter-hoarding rodent species were not limited to the woodland habitat, so the bird-passed seeds we found on the burned side of our study site, particularly under scattered trees that remained after fire, may contribute to expansion. Species such as the Great Basin pocket mouse, which moves freely between woodland and open habitats, could also be partly responsible for woodland expansion into sagebrush-steppe habitat or re-establishment of juniper on previously burned or clear-cut woodlands. By contrast, dispersal of juniper seeds by woodland dwelling species such as the piñon mouse probably results more in infilling of juniper trees within existing woodlands.

Understanding the role of seed dispersers can have important implications for management. For example, various management practices in Holm's oak (Quercus ilex) forest have been shown to alter scatter-hoarding behavior; rodents acted more as seed predators in fragmented forest, but increased caching as understory shrub cover increased above 65\% (Morán-López et al. 2016). Rodent abundance can also influence competition and, in turn, caching behavior (MoránLópez et al. 2016). Juniper management practices have generally been developed without considering effects of seed dispersers on re-establishment of trees after treatment. Thinning piñon-juniper woodlands and leaving slash piles increased piñon mouse abundance compared to untreated woodlands and thinned woodlands with slash removed (Severson 1986). The number of Ord's kangaroo rats (Dipodomys ordii) doubled after piñon-juniper woodlands were thinned, bulldozed, and burned, but decreased when woodland plots were just thinned or when they were thinned and bulldozed (Severson 1986). Piñon mice, chipmunks, and some species of kangaroo rats and pocket mice scatter-hoard juniper seeds (Dimitri 2016), so it is important to understand how juniper removal treatments influence abundances of these species. Cutting junipers with many seeds cached under the canopy and leaving behind shrubs and open microsites with seeds intact in the soil seed bank is not likely to be an effective longterm management strategy for converting expanding woodlands back to sagebrushsteppe habitat. It may be more efficient to focus on berry-producing trees along woodland ecotones where small mammal diversity is highest and junipers are encroaching into adjacent sagebrush-steppe habitat. Edges of burns should be given priority when implementing post-fire restoration seedings that aim to competitively suppress juniper reestablishment, as the woodland-open interface is where most of the seed dispersal that drives expansion occurs.

Juniper woodlands can provide important habitat for wildlife (Bombaci and Pejchar 2016). Thus, in juniper woodlands experiencing climate-induced mortality events, reforestation could be an important aspect of future management. These mortality events are predicted to increase as temperatures continue to rise (Allen et al. 2010), so understanding processes such as seed dispersal that influence seedling recruitment may be vital to maintaining sustainable woodlands. 


\section{ACKNOWLEDGMENTS}

We would like to thank Jon Bates and an anonymous reviewer for thoughtful comments that improved the manuscript. We also thank Jake Dittel and Chris Moore for constructive comments on an earlier version of the manuscript. This paper is a contribution of the USDA, Agricultural Research Service, Great Basin Rangelands Research Unit, Reno, NV.

\section{Literature Cited}

Adams, R.P., AND D. Thornburg. 2010. Seed dispersal in Juniperus: a review. Phytologia 92:424-434.

Allen, C.D., A.K. MacaladY, H. Chenchouni, D. BacheLet, N. McDowell, M. Vennetier, T. Kitzberger, A. Rigling, D.D. Breshears, and E.H. Hogg, ET AL. 2010. A global overview of drought and heatinduced tree mortality reveals emerging climate change risks for forests. Forest Ecology and Management 259:660-684.

BAKER, W.L., AND D.J. Shinneman. 2004. Fire and restoration of piñon-juniper woodlands in western United States: a review. Forest Ecology and Management 189:1-21.

Bombaci, S., and L. Pejchar. 2016. Consequences of pinyon and juniper woodland reduction for wildlife in North America. Forest Ecology and Management 365:34-50.

BurkhardT, J.W., and E.W. Tisdale. 1976. Causes of juniper invasion in southwestern Idaho. Ecology $57: 472-484$

Calviño-Cancela, M., M. Escudero, J. RodríguezPérez, E. Cano, P. Vargas, G. Velo-Antón, and A. Traveset. 2012. The role of seed dispersal, pollination and historical effects on genetic patterns of an insular plant that has lost its only seed disperser. Journal of Biogeography 39:1996-2006.

Chambers, J.C., and J.A. MacMahon. 1994. A day in the life of a seed: movements and fates of seeds and their implications for natural and managed systems. Annual Review of Ecology and Systematics 25 263-292.

Chambers, J.C., J.A. MacMahon, and J.H. Haefner. 1991. Seed entrapment in alpine ecosystems: effects of soil particle size and diaspore morphology. Ecology 72:1668-1677.

Chambers, J.C., S.B. Vander Wall, and E.W. Schupp. 1999. Seed and seedling ecology of piñon and juniper species in the pygmy woodlands of western North America. Botanical Review 65:1-38.

Chavez-Ramirez, F., and R.D. Slack. 1993. Carnivore fruit-use and seed dispersal of two selected plant species of the Edwards Plateau, Texas. Southwestern Naturalist 38:141-145.

Chavez-Ramirez, F., and R.D. SLaCK. 1994. Effects of avian foraging and post-foraging behavior on seed dispersal patterns of Ashe juniper. Oikos 71:40-46.

Clifford, M.J., N.S. Cobb, and M. Buenemann. 2011. Long-term tree cover dynamics in a pinyon-juniper woodland: climate-change-type drought resets successional clock. Ecosystems 14:949-962.
ConnelL, J.H. 1971. On the role of natural enemies in preventing competitive exclusion in some marine mammals and in rain forest trees. Pages 298-312 in P.J. den Boer and G.R. Gradwell, editors, Dynamics of populations. Center for Agricultural Publishing and Documentation, Wageningen, Netherlands.

DimitRI, L.A. 2016. Seed dispersal of western and Utah junipers: the role of scatter-hoarding rodents. Master's thesis, University of Nevada, Reno, NV.

ENDERS, M.S., AND S.B. VANDER WALL. 2012. Black bears Ursus americanus are effective seed dispersers, with a little help from their friends. Oikos 121:589-596.

Greenwood, D.L., and P.J. Weisberg. 2008. Densitydependent tree mortality in pinyon-juniper woodlands. Forest Ecology and Management 255:2129_ 2137.

Hollander, J.L., and S.B. Vander WaLl. 2004. Effectiveness of six species of rodents as dispersers of singleleaf piñon pine (Pinus monophylla). Oecologia 138:57-6.5.

Holthuijzen, A.M.A., T.L. Sharik, And J.D. Fraser. 1987. Dispersal of eastern red cedar (Juniperus virginiana) into pastures: an overview. Canadian Journal of Botany 65:1092-1095.

Horncastle, V.J., E.C. Hellgren, P.M. Mayer, D.M. ENGLE, AND D.M. Leslie JR. 2004. Differential consumption of eastern red cedar (Juniperus virginiana) by avian and mammalian guilds: implications for tree invasion. American Midland Naturalist 152:255-267.

Howe, H.F., AND M.N. Miriti. 2004. When seed dispersal matters. BioScience 54:651-660.

JANZEN, D.H. 1970. Herbivores and the number of tree species in tropical forests. American Naturalist 104:501-528.

KnapP, P.A., P.T. Soulé, and H.D. Grissino-Mayer. 2001. Post-drought growth response of western juniper (Juniperus occidentalis var. occidentalis) in central Oregon. Geophysical Research Letters 28:2657-2660.

LONGLAND, W.S., AND L.A. Dimitri. 2016. Are western juniper seeds dispersed through diplochory? Northwest Science 90:235-244.

Miller, R.F., J.D. Bates, T.J. Svejcar, F.B. Pierson, and L.E. Eddleman. 2005. Biology, ecology, and management of western juniper. Technical Bulletin 152 , Oregon State University, Agricultural Experiment Station, Corvallis, OR

Miller, R.F., AND J.A. Rose. 1999. Fire history and western juniper encroachment in sagebrush steppe. Journal of Range Management 52:550-559.

Miller, R.F., AND P.E. Wigand. 1994. Holocene changes in semiarid piñon-juniper woodlands. BioScience $44: 465-474$

Morán-López, T., T. Wiegand, J.M. Morales, F. ValLADARES, AND M. Díaz. 2016. Predicting forest management effects on oak-rodent mutualisms. Oikos 125:1445-1457.

Redmond, M.D., AND N.N. BARGER. 2013. Tree regeneration following drought- and insect-induced mortality in piñon-juniper woodlands. New Phytologist 200: $402-412$.

Rieder, J.P., T.A.S. Newbold, and S.M. Ostoja. 2010. Structural changes in vegetation coincident with annual invasion negatively impacts sprint velocity of small vertebrates. Biological Invasions 12:2429-2439.

Romme, W.H., C.D. Allen, J.D. Bailey, W.L. Baker, B.T. Bestelmeyer, P.M. Brown, K.S. Eisenhart, M.L. 
Floyd, D.W. Huffman, B.F. Jacobs et al. 2009 Historical and modern disturbance regimes, stand structures, and landscape dynamics in piñon-juniper vegetation of the western United States. Rangeland Ecology and Management 62:203-222.

Schupp, E.W., J.C. Chambers, S.B. Vander Wall, J.M. Gómez, and M. Fuentes. 1999. Piñon and juniper seed dispersal and seedling recruitment at woodland ecotones. Pages 66-70 in USDA Forest Service Proceedings RMRS-P-11.

Schupp, E.W., J.M. Gómez, J.E. Jiménez, AND M. Fuentes. 1997. Dispersal of Juniperus occidentalis (western juniper) seeds by frugivorous mammals on juniper mountain, southeastern Oregon. Great Basin Naturalist 57:74-78.

Severson, K.E. 1986. Small mammals in modified pinyon-juniper woodlands, New Mexico. Journal of Rangeland Management 39:31-34.

Soulé, P.T., and P.A. KNaPp. 2007. Topoedaphic and morphological complexity of foliar damage and mortality within western juniper (Juniperus occidentalis var. occidentalis) woodlands following an extreme meteorological event. Journal of Biogeography 34:1927-1937.

SPIEgEL, O., AND R. NATHAN. 2010. Incorporating density dependence into the directed-dispersal hypothesis. Ecology 91:1538-1548.
Van Auken, O.W. 2000. Shrub invasions of North American semiarid grasslands. Annual Review of Ecology and Systematics 31:197-215.

Vander WaLl, S.B. 1990. Food hoarding in animals. University of Chicago Press, Chicago, IL. 445 pp.

Vander Wall, S.B., and M.J. Beck. 2012. A comparison of frugivory and scatter-hoarding seed dispersal syndromes. Botanical Review 78:10-31.

Vander Wall, S.B., K.M. KunN, and J.R. GWoreK. 2005. Two-phase seed dispersal: linking the effects of frugivorous birds and seed-caching rodents. Oecologia 145:281-286.

Vander Wall, S.B., and W.S. Longland. 2004. Diplochory: are two seed dispersers better than one? Trends in Ecology and Evolution 19:155-161.

Weisberg, P.J., E. Lingua, and R.B. Pillai. 2007. Spatial patterns of pinyon-juniper woodland expansion in central Nevada. Rangeland Ecology and Management $60: 115-124$

Received 3 October 2016

Accepted 21 February 2017

Published online 13 July 2017 